\title{
Evalueringskriteria en die interaksie tussen die leksikografieteorie en -praktyk; die ontwerp van die Woordeboek van die Afrikaanse Taal as gevallestudie
}

\author{
P.H. Swanepoel, Departement Afrikaans en Algemene Literatuurwetenskap,
} Unisa, Pretoria, Suid-Afrika (swaneph1@unisa.ac.za)

Opsomming: Die samestellers van die verskillende dele van die WAT kon steun op die insette van verskeie medewerkers, waarvan woordeboekresensente 'n belangrike groep is. Een van die algemene probleme met die evaluering van woordeboeke van allerlei soorte (sien Nielsen 2006, 2009 en Swanepoel 2008, 2013 vir 'n bespreking) is dat daar egter in resensies - ook in sommige van dié van die verskene dele van die WAT - slegs gesteun word op kriteria vir die ontleding en beskrywing van die ontwerpkenmerke van woordeboeke en dikwels nie ook op 'n duidelik geformuleerde en gemotiveerde stel kriteria vir die evaluering van woordeboeke nie. Hierdie probleem en die onderskeid tussen beskrywingskriteria en evalueringskriteria en die inhoud, struktuur en operasionalisering van evalueringskriteria word in meer besonderhede in hierdie artikel bespreek na aanleiding van veral Feinauer (2007), Gouws (2007, 2011 en 2014), Gouws en Prinsloo (2005), Nielsen $(2006,2009)$ en Svensén (2009). Ten slotte word hierdie probleem toegelig aan die hand van die ontwerpkenmerke van WAT Deel XIV.

Sleutelwoorde: WOORDEBOEKRESENSIES, WOORDEBOEKBESKRYWINGSKRITERIA, WOORDEBOEKEVALUERINGSKRITERIA, DIE VORM, INHOUD EN OPERASIONALISERING VAN LEKSIKOGRAFIESE EVALUERINGSKRITERIA, ONTWERPKENMERKE VAN WAT DEEL XIV

\begin{abstract}
Evaluation criteria and the interaction between lexicographic theory and practice; the design of the Woordeboek van die Afrikaanse Taal as case study. The compilers of the various volumes of the WAT have relied on input from various co-workers, of which dictionary reviewers form an important group. However, a common problem with the evaluation of dictionaries of various kinds (cf. Nielsen 2006, 2009 and Swanepoel 2008, 2013) is that reviews only provide an analysis and description of the design features of dictionaries and not also an evaluation based on a set of clearly formulated and motivated criteria for the evaluation of dictionaries. This problem, the distinction between criteria for the description and evaluation of the design features of dictionaries, and the content, structure and operationalization of lexicographic evaluation criteria, are discussed in this article, taking especially Feinauer (2007), Gouws (2007, 2011, 2014), Gouws and Prinsloo (2005), Nielsen $(2006,2009)$ and Svensén (2009) as
\end{abstract}


point of departure. Finally, this lexicographic problem is discussed with reference to the design features of WAT Volume XIV.

Keywords: DICTIONARY REVIEWS, DICTIONARY DESCRIPTION CRITERIA, DICTIONARY EVALUATION CRITERIA, THE FORM, CONTENT AND OPERATIONALIZATION OF LEXICOGRAPHIC EVALUATION CRITERIA, DESIGN FEATURES OF WAT, VOLUME XIV

\section{Inleiding}

Met die ontwerp van die verskillende dele van die Woordeboek van die Afrikaanse Taal (afgekort tot WAT) het die redaksie tot dusver kon profiteer van bydraes van verskeie ander medewerkers: taalliefhebbers, gebruikers van die WAT, kenners van verskillende vakgebiede, (Suid-)Afrikaanse taalkundiges, leksikograwe, kenners van die leksikografieteorie en resensente wat in akademies geakkrediteerde media publiseer (sien Nielsen 2009: 208-210 en die bedankings in die voortekste van die verskene dele van WAT en resensies soos dié van Boshoff 1926; Combrink 1962, 1979; Feinauer 1996, 2007; Gouws 1985, 1994; Grobler 1978; McLachlan 2010; en Odendal 1961a, b, 1962).

Resensente het egter die moeilike taak om nie net 'n beskrywing van die ontwerpprosesse en ontwerpkenmerke (soms verkort tot: ontwerp) van die verskillende (dele van) woordeboeke, soos die verskene dele van die WAT, te gee nie, maar hulle moet ook 'n evaluering van die betrokke woordeboek(-dele) aanbied.

Een van die algemene probleme met die evaluering van woordeboeke van allerlei soorte (sien Swanepoel 2008 en 2013 vir 'n bespreking) is dat die voorskrifte, wenke, matrikse of leidrade vir sulke resensies dikwels uit nie veel meer bestaan nie as 'n reeks rubrieke - gewoonlik 'n lysie van die makro- en die mikrostruktuurkenmerke - vir die ontleding van die ontwerpkenmerke van 'n woordeboek (van 'n bepaalde tipe). Kriteria vir die evaluering van hierdie kenmerke van woordeboeke word selde verskaf (sien Nielsen 2006, 2009 en Swanepoel 2013). Die gevolg is dat meeste resensies niks meer as 'n ontleding van die ontwerpkenmerke van 'n woordeboek is nie.

In ander gevalle word wel evaluering van die ontwerpkenmerke van 'n woordeboek verskaf, maar sulke uitsprake is dan gebaseer op die intuïsie of ervaring van die resensent in die rol van 'n enkele gebruiker van die betrokke woordeboek (of dan 'n enkele ingeligte gebruiker). Soms verwys resensente na die feit dat gebruikers van die woordeboek (heelwaarskynlik) baat sou vind deur alternatiewe of bestaande ontwerpkenmerke of -benaderings (byvoorbeeld ten opsigte van die vindbaarheid of verstaanbaarheid van data in ' $n$ woordeboek), maar sonder dat hierdie soort evaluatiewe uitsprake deur 'n motivering onderbou word (byvoorbeeld motivering vanuit teoreties-gedrewe empiriese navorsing). Dit laat veel te wense oor as resensente eenvoudig hulle persoonlike oordeel oor die ontwerp van 'n woordeboek veralgemeen na alle potensiële teikengebruikers daarvan, of as enigste motivering vir evaluatiewe 
uitsprake volstaan word met verwysings na die voorkeure, afkeure, woordeboekgebruikersvaardighede, ensovoorts van teikengebruikers wat nie self empiries afgebaken is nie of as die gebruik van 'n woordeboek nie nagevors is nie.

Resensente het dikwels ook die neiging om skerp kritiek op bepaalde woordeboeke/-dele te lewer op basis van die oortreding van kriteria waarvoor daar geen duidelike motivering verskaf word nie, of waarvan dit nie presies aangedui word hoe resensente 'n bepaalde kriterium vir die evaluering van die ontwerpkenmerke van 'n woordeboek moet operasionaliseer nie (sien byvoorbeeld Grobler 1978).

'n Verdere probleem met die beskrywing en evaluering van die WAT in die besonder is dat daar min beskikbare navorsingsliteratuur is oor die inhoud en struktuur en die gebruik al dan nie van beskrywingskriteria en evalueringskriteria in die resensies van verskillende dele van die WAT. Verder is dit nie duidelik of en hoe die samestellers van die WAT resensies soos dié wat bo vermeld word gebruik in die hersiening van verskene dele van die WAT of die beplanning en samestelling van nuwe dele nie. Sien egter in hierdie verband Botha $(2004,2006)$.

Die eerste doelstelling van hierdie artikel is gevolglik om hierdie probleem van die evaluering van woordeboeke te bespreek aan die hand van die kriteria wat Svensén (2009: 480-487) vir 'n "goeie" leksikografiese resensie/woordeboekkritiek bied. Tweedens word hierdie probleem belig vanuit Gouws (2007, 2011 en 2014). In Gouws (2014) word 'n driedeling van die historiese ontwikkeling van die leksikografieteorie (en -praktyk) aangebied: die linguistiese benadering, die struktuurbenadering en die funksionele benadering, wat verskeie moontlikhede vir die ontwikkeling van beskrywings- en evalueringskriteria vir resensente bied. Dieselfde geld vir Gouws (2007) se voorstel vir die uitbreiding van die leksikografiese funksies vir 'n woordeboek na al die tekste daarvan (voortekste, agtertekste, mediotekste, sentrale woordelys, ensovoorts).

In hierdie artikel word daar dus doelbewus afgewyk van die navorsingsmetodologie oor resensies wat op basis van die inhoud van 'n korpus resensies (as't ware van onder na bo) empiriese data genereer vir die ontleding, beskrywing en evaluering van woordeboekresensies (sien byvoorbeeld Chan en Taylor 2001; Ripfel 1989).

Tweedens word daar 'n voorlopige raamwerk aangebied vir die ontleding en beoordeling van evalueringskriteria self (sien ook Swanepoel 2008 en 2013), alvorens ' $n$ kort bespreking van die ontwerpkenmerke van WAT XIV verskaf word.

Volgens Botha (2004: 16) moet daar in die leksikografie 'n voordelige wisselwerking tussen die leksikografieteorie en -praktyk wees en dat die ontwerp van spesifieke woordeboeke "steeds die stand van die metaleksikografie (of leksikografieteorie - PHS) sal weerspieël". Daarmee het die WAT, by name van die huidige hoofredakteur, daarvoor ' $n$ baie belangrike evalueringskriterium gestel, naamlik die mate waarin die redaksionele beleid en praktiese ontwerp van dele van die WAT aan die bestaande ontwikkelinge op die gebied van die 
leksikografieteorie voldoen.

Die hoofdoel van hierdie artikel is nie om ' $n$ volledige resensie van WAT Deel XIV aan te bied nie. Die fokus val eerstens op die problematiese aspekte van resensies van woordeboeke, en dié word ten slotte kortliks betrek op die ontwerpkenmerke van WAT Deel XIV.

\section{Vereistes aan woordeboekresensies}

Svensén (2009: 485) meld dat woordeboekresensies verskillende doelstellinge/ funksies kan hê, waarvan die volgende vier die belangrikste is:

- Beskrywing

- Evaluering

- Motivering van/redes vir evaluering

— Raad/"Advice" (aan potensiële kopers en woordeboeksamestellers — PHS).

Svensén (2009: 482) wys dan daarop dat daar al bespiegel is oor watter van hierdie elemente as verpligtend vir 'n woordeboekresensie beskou moet word. Sy eie uitgangspunt is dat dit wel moontlik is om resensies te produseer wat slegs 'n beskrywing (van die ontwerpprosesse en ontwerpkenmerke) van 'n woordeboek bied, maar dat 'n goeie resensie (Engels: "regular review") ook 'n evaluering van hierdie kenmerke, 'n motivering vir elkeen van die gekose evalueringskriteria en advies vir potensiële gebruikers (en die samestellers van 'n woordeboek) moet verskaf.

Svensén (2009: 483) fokus veral op kriteria vir die beskrywing van die ontwerpkenmerke van 'n woordeboek, en hiervoor gooi hy die net breed uit deur nie minder nie as ses en dertig beskrywingsrubrieke vir die ontleding van die ontwerp van 'n eentalig verklarende woordeboek aan te bied. Die matriks word in vertaalde en aangepaste vorm hier onder angebied omdat die rubrieke elkeen ook 'n aspek van die ontwerpkenmerke van 'n omvattende woordeboek soos die WAT dek.

\begin{tabular}{|l|l|}
\hline 1 woordeboekfunksies & 19 grammatika \\
\hline 2 woordeboekgebruikers & 20 ortografie \\
\hline 3 voorligting aan gebruikers & 21 uitspraak \\
\hline 4 prys & 22 semantiese en ensiklopediese inligting \\
\hline 5 uitleg/webontwerp & 23 diasistemiese inligting \\
\hline 6 die samestellers & 24 etimologie \\
\hline 7 vergelyking met ander woordeboeke & 25 voorbeelde (sitate en poeëme) \\
\hline 8 voorgeskiedenis van die woordeboek & 26 kollokasies \\
\hline
\end{tabular}




\begin{tabular}{|l|l|}
\hline 9 verwysing na ander resensies & 27 idiome \\
\hline 10 die resensent & 28 illustrasies \\
\hline 11 woordeboekbasis/-dataversameling & 29 sinonimie/antonimie \\
\hline 12 voortekste & 30 kruisverwysings \\
\hline 13 lemmaseleksie & 31 vermaaklikheidswaarde \\
\hline 14 bepaling van lemmas vir opname & $\begin{array}{c}32 \text { opsommende/samevattende slotevalu- } \\
\text { ering }\end{array}$ \\
\hline 15 soek- en toegangstrukture & 33 tipes en graad van tekstuele verdigting \\
\hline 16 artikelstruktuur & $\begin{array}{c}34 \text { makrostruktuur (seleksie en rangskik- } \\
\text { king van lemmas) }\end{array}$ \\
\hline 17 normatiewe/deskriptiewe dimensie & 35 morfologiese inligting \\
\hline 18 ekwivalente & $\begin{array}{c}36 \text { opname van seksuele, ras- , godsdiens- } \\
\text { tige en nasionaliteitstereotipes }\end{array}$ \\
\hline
\end{tabular}

Alhoewel 'n resensie volgens Svensén (2009: 484) nie al hierdie aspekte van die ontwerp van 'n woordeboek moet dek om as "perfectly satisfactory" beskou te word nie, bied hy self nie duidelikheid oor hoe mens aan die hand van hierdie rubrieke ' $n$ resensie van ' $n$ woordeboek kan opstel en self evalueer na gelang van die graad van "bevrediging" ("satisfaction") wat 'n resensie bied nie (en, sou mens ook kon vra: Vir wie ook al?); byvoorbeeld, Svensén (2009: 452-479) gee self geen verdere leiding oor watter aspekte van die funksies en gebruikers van ' $n$ bepaalde woordeboek, die voortekste, agtertekste of die makro- en mikrostrukturele kenmerke van die sentrale woordelys ontleed en bespreek moet word nie.

Rubrieke 33-36 neem Svensén (2009: 483) nie as deel van sy matriks op nie, maar noem dit wel as aspekte wat vir die ontleding en beskrywing van die ontwerp van 'n woordeboek geneem kan word. Sommige hiervan (byvoorbeeld 34 en 35) sou onder van die voorafgaande rubrieke bespreek kon word. Uiteraard sou meerdere ontwerpkenmerke bygevoeg kon word. 'n Duidelike leemte in hierdie matriks is byvoorbeeld die feit dat daar geen rubriek vir die ontleding en beskrywing van die agtertekste van 'n woordeboek is nie.

Gegee verder die gebrek aan aanvullende omskrywinge van die rubrieke as beskrywingskriteria, is dit selfs moeilik om 'n matrys soos die bostaande te gebruik as kontrolemiddel vir die volledigheid van woordeboekresensies, of voortekste, soos die gebruikerstekste, of die sentrale woordelys van 'n woordeboek. Hiervoor sal 'n matriks soos die bostaande vir die ontleding en beskrywing van enige - veral die omvattende - woordeboek heelwat aanvulling moet kry. Resensente sou byvoorbeeld meer lig op die leksikografiese status van die rubrieke as beskrywingskriteria kon werp deur te gaan kyk wat leksikograwe in hulle redaksionele ontwerpbeleid oor elkeen sê, 'n studie maak van 
die gebruikersinligting - indien volledig genoeg - as dit in 'n woordeboek (gewoonlik as voorteks) verskaf word, of die magdom navorsingsliteratuur oor die gebruik van elkeen van hierdie rubrieke as 'n kriterium vir die ontleding en beskrywing van ('n aspek van) 'n woordeboek. 'n Alternatiewe metode sou wees om die moeisame pad te volg om alle werke wat reeds as handboeke vir die samestelling van woordeboeke die lig gesien het, vir beskrywingskriteria (en evalueringskriteria) te myn (sien byvoorbeeld Atkins en Rundell 2008; Fontenelle 2008; Gouws en Prinsloo 2005; Hausmann 1989-1991; Svensén 2009; Van Sterkenburg 2003; Zgusta 1971).

Benewens die stel van die vereistes dat ' $n$ resensie ' $n$ evaluering van die ontwerpkenmerke van 'n woordeboek moet bied en 'n motivering vir die gekose evalueringskriteria moet verskaf, gee Svensén baie beperk aandag aan die ontwerp (inhoud, struktuur, vorm) en operasionalisering van elkeen van die leksikografiese evalueringskriteria en hulle motivering soos hulle op elkeen van die rubrieke in hierdie matriks betrekking het; byvoorbeeld: Daar word nie vermeld volgens watter kriteria die keuse van en inligting oor die gebruikers en gekose funksies van 'n woordeboek geëvalueer moet word nie, of watter motivering daar bestaan vir die keuse van spesifieke kriteria hiervoor nie. Svensén (2009) bied ook wat die evaluering van resensies betref, geen kruisverwysings na relevante dele van die teks van sy boek nie, maar volstaan met ' $n$ klein handjie vol relevante navorsingsliteratuur oor woordeboekresensies (sien Svensén 2009: 487).

Svensén (2009: 485-486) keer egter na die onderwerp van die evaluering van woordeboeke terug onder die titel "Demands on a good dictionary review" en meld, veral na aanleiding van die beskouings van Nielsen (2003), enkele bykomende kriteria vir die evaluering van resensies self (Svensén 2009: 485486). ' $n$ Oorkoepelende vereiste van Nielsen is dat 'n resensie ' $n$ regverdige ("fair") weergawe van 'n woordeboek en die kenmerke daarvan moet gee. Om dit te bereik, word die volgende vereistes gestel aan 'n resensie:

- 'n Resensie moet net relevante inligting verskaf en evaluerings maak, dit wil sê, die inligting en evaluerings moet gekoppel wees aan die doelstellings van die woordeboek en bruikbaar wees vir die gekose teikengroep.

- 'n Resensie moet fokus op essensiële kenmerke van 'n woordeboek, dit wil sê dit moet slegs die kenmerke bespreek wat, indien hulle uit die resensie weggelaat sou word, 'n verkeerde indruk van die gehalte van die woordeboek kan skep.

- 'n Resensie moet betroubaar wees, dit wil sê dit moet nie verkeerde inligting bevat nie of steun op ongegronde stellings wat die potensiële gebruiker se opvatting van die woordeboek negatief kan beïnvloed.

- ' $n$ Resensie moet neutraal wees deurdat dit alle relevante en essensiële uitgangspunte moet bevat, dit wil sê die resensent moet hom/haar nie deur haar/sy eie voorkeure in hierdie verband laat lei nie. 
Svensén (2009: 485-486) voeg ook nog die volgende by:

- 'n Resensie moet nie in algemene terme geklee wees nie, maar fokus op spesifieke kenmerke van 'n woordeboek, soos die datakategorieë wat dit bevat.

- As 'n resensie na foute in die ontwerp van 'n woordeboek verwys (byvoorbeeld die weglating van lemmas), moet die resensent (byvoorbeeld by wyse van steekproewe) aandui hoe frekwent 'n afwyking/fout voorkom en hoe ernstig dit opgeneem moet word in die evaluering van 'n woordeboek (byvoorbeeld elke bladsy, sporadies deur die hele woordeboek, ensovoorts).

- In 'n resensie moet die slotevaluering die korrekte afleidings maak uit evaluerings wat vroeër in die resensie gegee word, dit wil sê as 'n resensie die ontwerp van 'n woordeboek net/oorwegend as negatief beoordeel, dan kan die slotevaluering nie met ' $n$ positiewe algemene evaluering eindig nie.

Uit Svensén (2009) is daar dus 'n stuk of elf kriteria vir die evaluering van die resensie van ' $n$ woordeboek af te lei. Naas die feit dat 'n resensie ' $n$ bespreking van die ontwerpkenmerke van 'n woordeboek moet bevat, moet dit ook 'n evaluering van hierdie kenmerke verskaf, ' $n$ motivering bied vir elke evalueringskriterium en 'n slot-, opsommende evaluering van ' $n$ woordeboek gee.

Relevante evalueringskriteria (hier geformuleer as vrae) - al is dit nie altyd duidelik oor presies hoe dié beantwoord moet word nie - is die volgende soos afgelei uit Nielsen (2003) hierbo:

- Bevat die resensie net relevante inligting?

- Fokus die resensie net op essensiële kenmerke van 'n woordeboek?

- Is die resensie betroubaar?

- Is die resensie neutraal?

- Fokus die resensie op spesifieke kenmerke van die ontwerp van 'n woordeboek?

- Word daar in 'n resensie ondersteuning uit die woordeboek self gebied vir die frekwensie en omvang van foute wat in die ontwerp van 'n woordeboek uitgewys word?

- Is die slotevaluering in ' $n$ resensie korrek afgelei uit die positiewe of negatiewe evaluerings wat vroeër in die resensie verskaf word?

Skakel mens dus Svensén (2009) se kriteria vir die skryf van 'n goeie resensie van 'n woordeboek om na 'n stel evalueringskriteria, dan is dit al moontlik om ten minste sommige aspekte van ' $\mathrm{n}$ resensie te beoordeel. Die kriteria is egter 
vaag geformuleer en daar word nie presies aangedui hoe hulle vir die beoordeling van resensies geoperasionaliseer moet word nie. Hierdie punt word verder opgeneem hieronder.

Nielsen (2009: 211) meld verder dat resensente in hulle resensies 'n getroue ("faithful") weergawe van leksikografiese elemente van 'n woordeboek moet verskaf, en dat ' $n$ getroue weergawe net moontlik is as alle teksdele van ' $n$ betrokke woordeboek ontleed en beoordeel word; dus: ook aandag gee aan alle voor-, medio- en agtertekste en nie net die sentrale woordelys nie. Hierdie kriterium het in hoofsaak betrekking op die omvang van die woordeboek wat in 'n resensie aan die bod moet kom. As evalueringskriterium vir ' $n$ resensie kan hierdie vereiste soos volg geformuleer word:

- Behandel en evalueer ' $n$ resensie alle samestellende tekste van 'n woordeboek?

Nielsen $(2006,2009)$ wys byvoorbeeld daarop dat baie resensente eenvoudig in hulle resensies belangrike voortekste, mediotekste of agtertekste buite beskouing laat. Die beskrywing en evaluering van tekste wat (as voortekste) inligting verskaf oor die gebruik van woordeboeke (gebruiksgidse) word byvoorbeeld dikwels eenvoudig weggelaat of slegs op minimale wyse in resensies behandel.

\section{Woordeboekontwerp en -evaluering en die interaksie met leksikografiese teorieë}

Gouws (2014) tref 'n onderskeid tussen drie komplementerende fases in die ontwikkeling van die leksikografieteorie en -praktyk: die linguistiese era waarin linguistiese teorieë die basis vir die beplanning, ontwikkeling (en uiteindelike evaluering) van 'n woordeboek was (sien veral Zgusta 1971); die era van woordeboekstruktuur waarin daar veral uitgebrei is op die struktuurkenmerke van woordeboeke en, maar in kleiner mate, die vereiste dat die ontwerp van 'n woordeboek deur die beoogde funksies en teikengebruikers daarvan bepaal moet word (sien veral Wiegand 1996; Gouws 2014); en die funksionalistiese benadering van die Arhausskool (Tarp en Bergenholtz; sien byvoorbeeld Tarp 2004a en b) waarvolgens die ontwerp en evaluering van 'n woordeboek bepaal moet word deur die linguistiese en leksikografiese vaardigheide van die beoogde teikengebruikers daarvan en die funksie(s) waarvoor die woordeboek ingespan word in verskillende gebruikskontekste.

Gouws stel dit duidelik dat Zgusta (1971) die noodsaak bevestig van 'n linguisties-teoretiese begronding van die ontwerp en uiteindelik evaluering van woordeboeke en vir 'n noue interaksie tussen leksikografieteorie en -praktyk (Gouws 2014: 379). Omgeset is daar hier sprake dat nie net die ontwerp en samestelling en die ontleding en beskrywing van die ontwerp van 'n woordeboek op basis van 'n duidelik en omvattende ('n) linguistiese teorie(ë) moet geskied nie, maar ook vir die evaluering daarvan. In laasgenoemde geval kan 
'n linguistiese teorie (as deel van omvattender leksikografieteorie) ook vir die evaluering en die motivering van die ontwerpkenmerke van 'n woordeboek dien; ter illustrasie: Die vertrekpunte van die tradisionele grammatika en die strukturalisme is in Zgusta (1971) 'n kernelement van die leksikografieteorie wat hy voorstaan. Hierdie teorie(ë) bepaal ook sy voorstelle vir die beplanning en ontwerp van 'n woordeboek (die seleksie, inhoud en strukturering van linguistiese data). Die evaluering van die ontwerpkenmerke van 'n woordeboek kan gevolglik gemeet word in dié mate waarin 'n woordeboek aan die vereistes van die betrokke teorie voldoen. Die kriteria wat hiervoor ingespan word, is gemotiveer vir sover daar empiriese ondersteuning vir die betrokke linguistiese teorie(ë) is. (Sien die bespreking hieronder.)

Wat Gouws (2014) oor die interaksie tussen woordeboekontwerp en die linguistiek/leksikografie hierbo maak, noop mens om weer Zgusta (1971) van vooraf en enduit te bestudeer. Hierdie werk laat sien hoe Zgusta linguistiese en leksikografieteorieë integreer om oplossings te bedink vir bepaalde leksikografiese probleme wat hulle voordoen in enige poging om 'n omvattende beskrywing, maar veral van die betekenisinhoud en -struktuur van die leksikale items (sien Zgusta 1971: 21-118) van 'n taal in 'n omvattende woordeboek te gee (sien Zgusta 1971: 222-293). In die geheel gesien, lewer die aangeduide dele van Zgusta 'n omvattende, linguisties gemotiveerde deskriptiewe raamwerk vir die ontwerp (sowel die ontwerpproses, as die ontwerpkenmerke), evaluering en die motivering van die kriteria vir laasgenoemde. (Sien ook Zgusta se bespreking van die leksikografiese hantering van meerwoordige leksikale items (1971: 138-163) en leksikale variëteit- en leksikale stylverandering (1971: 164-197) en die mikrostrukturele data-elemente wat ten opsigte van elke lemma verskaf moet word.)

Gouws (2011: 137) sluit indirek by laasgenoemde aan as hy dit stel dat die omvattendheid van 'n woordeboek bepaal word deur die omvang van die leksikale items wat as lemmas ingesluit word, die spektrum van die leksikon van 'n taal wat gedek word (byvoorbeeld die keuse van verskillende variëteite en dialekte), die verskeidenheid datatipes wat vir bewerking ingesluit word en die aard en omvang van hulle bewerking. Presies wat elkeen hiervan behoort te behels, kan slegs gespesifiseer word met 'n omvattende linguistiese teorie oor die leksikon van 'n taal (omvang, inhoud, struktuur, ens.) en op basis van een wat ook empiriese ondersteuning geniet.

Die linguisties teoretiese benadering is kenmerkend van die (sy dit ouer) eentalig verklarende woordeboeke - 'n feit wat volgens Nielsen $(2006,2009)$ veral daaruit spreek dat die gebruikstoeligting in meeste woordeboeke van hierdie soort fokus op die makrostruktuur (opname en strukturering van lemmas) en die mikrostruktuur daarvan, d.i. die linguistiese inhoud, struktuur, bewerking, ensovoorts in afsonderlike artikels van die sentrale woordelys. Sowel die ontwerp van hierdie soort woordeboek en die beskrywing en evaluering daarvan in resensies word dus op eksplisiete linguistiese teorieë gebaseer.

Die benadering van die Wiegand-era fokus veral op die ontwikkeling van 
'n analitiese apparaat vir die ontleding van woordeboekstrukture soos wat hulle empiries in verskillende woordeboeksoorte gestalte kry. Bekende en nuwe terme wat hierop betrekking het, is byvoorbeeld raamstruktuur, geïntegreerde en niegeïntegreerde voortekste en agtertekste, sentrale woordelys, dataverspreidingstruktuur, makro- en mikrostruktuur, artikelstruktuur, adresseringstruktuur, toegangstruktuur, mediostruktuur, ensovoorts. (Sien Gouws 2014; Gouws en Prinsloo 2005; Wiegand 1996 vir 'n uitgebreide bespreking van hierdie terme.)

Die tweede stel evalueringskriteria blyk uit Gouws se bespreking van die Wiegand-era en die kriteria wat daar ter sake gebring word:

Die data (in 'n woordeboek - PHS) word aangebied sodat die teikengebruikers van die betrokke woordeboek die nodige inligting aan die aangebode data kan onttrek. 'n Optimale inligtingsonttrekking is slegs moontlik indien die teikengebruikers toegang tot die data kry en dit op 'n ondubbelsinnige manier kan interpreteer. Die verpakking speel ook 'n belangrike rol in die sukses van woordeboeke. ... Daar is ook toenemend aandag gegee aan die mate waarin die teikengebruiker en sy of haar behoeftes en naslaanvaardighede 'n invloed moet hê op die inhoud en aanbieding van elke woordeboek. (Gouws 2014: 379-380)

Hieruit blyk byvoorbeeld die volgende as kriteria wat vir die beoordeling van 'n woordeboek sou kon geld: die mate waarin woordeboekgebruikers optimaal hulle inligtingsbehoeftes uit die aangebode data kan onttrek, met as subevalueringskriteria: die mate waarin woordeboekgebruikers toegang tot die data (vir spesifieke funksies) verkry en die mate waarin woordeboekgebruikers die aangebode data op ' $n$ ondubbelsinnige manier kan interpreteer. Daarnaas is daar nog kriteria soos die volgende: die mate waarin die verpakking van die data as suksesvol beskou kan word; die mate waarin die ontwerp van 'n woordeboek aan die naslaanvaardighede van die woordeboekgebruikers voldoen; die mate waarin ' $n$ woordeboek spesifieke data aanbied vir elke funksie waarvoor die gebruikers 'n woordeboek kan gebruik.

Kernprobleme met hierdie soort verhulde aanbieding van evalueringskriteria is dat die kriteria self nie eksplisiet as evalueringskriteria aangebied word nie, die kriteria self vaag geformuleer is (Hoe interpreteer en meet mens byvoorbeeld die mate waarin...x?) en dat daar geen duidelike riglyne is oor hoe ' $n$ resensent in die beoordeling van 'n woordeboek elkeen van hierdie kriteria in die praktyk kan/moet toepas nie. Meer algemeen: Daar word nie aangedui hoe elkeen van die kriteria in die praktyk geoperasionaliseer moet word vir die evaluering van 'n woordeboek nie.

Die mate waarin ' $n$ woordeboek aan enige van hierdie kriteria voldoen, is egter ook 'n empiriese vraag wat in die beoordeling van 'n woordeboek empiries getoets moet word. Waar sulke navorsing wel bestaan, lewer die resultate dikwels verrassinge op. 'n Goeie voorbeeld hiervan is die empiriese toetsing van Cumming et al. (1994) van die aanname dat die volsin- leksikografiese definisie ' $n$ beter soort definisie is as die sinstuk-leksikografiese definisie. Wat hulle navorsing toon, is egter dat daar geen beduidende verskil in produksietake is wat gebaseer is op die volsin- of sinstukdefinisies nie (sien verder Swanepoel 2000). 
Die gebrek aan teoreties-gestuurde empiriese navorsing ter ondersteuning van leksikografiese evalueringskriteria blyk ook duidelik in die geval van die soort leksikografiese funksionalisme van Tarp en Bergenholtz (sien Gouws 2014). Hiervolgens moet die ontwerp van 'n woordeboek (inhoud, struktuur, ens.) bepaal word deur die funksies (kommunikatief, kognitief, operasioneel en interpretatief) waarvoor spesifieke kategorieë taalgebruikers (met inagneming van hulle taalvaardigheid en naslaanvaardigheid) die woordeboek in spesifieke gebruikskontekste vir bepaalde inligtingsbehoeftes inspan.

Die kommunikatiewe funksies word byvoorbeeld verder verdeel in enkoderings- en dekoderingstake. Die outeurs bied op basis van hulle eie kennis of intuïsie van wat elkeen van hierdie take aan data op die makro- en mikrostrukturele vlak van 'n woordeboek vereis (sien Tarp 2004a, b). Geen empiriese navorsing word ingespan om inderdaad te bepaal watter leksikografiese data spesifieke woordeboekgebruikers vir watter funksies in bepaalde gebruikskontekste inspan nie. Trouens, een van die kenmerke van hierdie vorm van leksikografiese funksionalisme is dat die meeste empiriese leksikografiese navorsing as oorbodig vir óf die ontwerp óf die evaluering van woordeboeke verklaar word. (Sien byvoorbeeld Tarp 2009.)

Nielsen (2006) volg 'n verwante, maar tog verskillende benadering. Aanvanklik beklemtoon hy die noodsaak vir empiriese navorsing oor woordeboekfunksies, -gebruikers en gebruikskontekste (Nielsen 2006: 3) vir die ontwerp van woordeboeke, maar by gebrek aan hierdie soort navorsing slaan hy al hoe meer oor na die modale kwalifisering van sy bespreking van die ontwerp en evaluering van woordeboeke met die woordjie "may". (Sien byvoorbeeld Nielsen 2006: 5 se uitlating dat "dictionaries may be multifunctional".)

Hierdie benadering tot die ontwerp en evaluering van woordeboeke steun metodologies op die deduktiwisme (en nie die induktiwisme nie), dit wil sê die ontwerp en evaluering van ' $n$ woordeboek word nie ondersteun deur teoreties gedrewe empiriese leksikografiese navorsings nie, maar daar word vanuit die intuïsie, kennis of ervaring van die leksikograaf 'n teorie geponeer vir sowel die ontwerp as evaluering van 'n woordeboek. Hierdie soort funksionalisme is gevolglik ook niks meer as ' $n$ teorie nie wat om empiriese toetsing vra alvorens die status van die ontwerp- en evalueringskriteria wat mens daaruit sou kon aflei, beoordeel kan word.

Gegee dat soveel idees oor die ontwerp en evaluering van woordeboeke op basis van funksies gebaseer is op ingeligte opinie, meld Swanepoel (2000: 405) die volgende:

Given that current thinking on the FQ (=Functional quality; PHS) of dictionaries is for a great deal based on personal experience, I will first tackle the status of subjective experience as a source of our knowledge on the complexities of the FQ of dictionaries.

Although lexicographical and pedagogical experience or "informed opinion" can guide hypothesis formation in theory construction and empirical testing, alone it is not enough to elucidate the real problems learners experience with the functionality of dictionaries. For one, these assumptions may simply be wrong, 
misguided or have little empirical support beyond the limits of the lexicographer's, teacher's or even dictionary reviewer's own subjective experience ...).

Wat egter ook duidelik is, is dat die deduktiwistiese benadering van Tarp en Bergenholtz oor die funksionele ontwerp van woordeboeke 'n baie belangrike bydrae gelewer het en nog steeds lewer tot die ontwikkeling van die leksikografieteorie, leksikografiese praktyk en die evalueringskriteria van woordeboeke - al vra hierdie bydraes om verdere empiriese toetsing.

'n Belangrike bydrae tot die ontwikkeling van woordeboekfunksies is egter Gouws (2007) (sien ook Nielsen 2006, 2009), wat die funksionele ontwerp en evaluering van woordeboeke uitbrei van die sentrale woordlys na die buitetekste (voor- en agtertekste) toe. Die eerste evalueringskriterium wat hy stel, is dat 'n woordeboek in die gebruikerstoeligting (as voorteks) die gebruiker moet inlig van al die strukture en funksies van die woordeboek as geheel en hoe die gekose strukture en funksies die ontwerp van al die samestellende tekste van ' $n$ bepaalde woordeboek bepaal. Die noodsaak hiervoor, en veral dat daar vir woordeboekgebruikers 'n omvattende, maklik toeganglike gebruiksgids as voorteks gegee moet word en dat hulle deeglik daarvan moet kennis neem, word daarin gemotiveer dat sonder hierdie kennis gebruikers moeilik die data in die res van 'n woordeboek sal kan ontsluit (sien Gouws 2007: 80-81). Gebruiksgidse wat wel so ontwerp is, is geïntegreerde tekste vir sover hulle gebruikers help om die relevante inligting te vind vir die uitvoering van die funksie(s) wat die woordeboek in sy ontwerp in die oog het.

Gouws (2007: 84-85) gee as voorbeelde van agtertekste wat wel 'n duidelike funksie het maar waarvan die funksie van die sentrale teks kan verskil, 'n lys van vleissnitte met illustrasies en gedetailleerde (geografiese) kaarte. Hierdie agtertekste het duidelik primêr ' $n$ kognitiewe funksie (uitbreiding van die kennis van die gebruiker) en dié kan funksioneel verskil van 'n sentrale lys wat primêr 'n kommunikatiewe funksie (enkodering en dekodering van tekste) het.

Nielsen $(2006,2009)$ fokus ook op die funksionele ontwerp van woordeboeke en veral die gebruikstekste, en stel daarmee ook 'n aantal kriteria vir die evaluering van funksionele gebruikstekste. Volgens Nielsen (2009: 215) het 'n funksioneel ontwerpte woordeboek die volgende kenmerke:

- Dit is ontwerp om een of meer funksies te ondersteun.

- Die opgenoemde data is geselekteer omdat hulle spesifieke woordeboekfunksies ondersteun.

- Struktureel is ' $n$ woordeboek so ontwerp dat die data die gekose funksies kan ondersteun.

In die bespreking van die ontwerp van gebruikstekste onderskei Nielsen (2006) duidelik tussen woordeboeke waarvan die ontwerp deur een of meer linguistiese teorieë bepaal word en dié wat deur die funksionele benadering bepaal is. Eersgenoemde fokus in die gebruikstekste op die linguistiese inhoud en struk- 
tuur van die betrokke artikels van die sentrale woordelys. Funksioneel ontwerpte gebruiksgidse, daarenteen, gee 'n uiteensetting van die verskillende maniere waarop die gebruiker die woordeboek kan gebruik om bepaalde funksies (spesifieke inligtingsbehoeftes in spesifieke gebruikskontekste) uit te voer. Ontwerpsgewyse stel Nielsen (2006) voor dat 'n funksioneel ontwerpte gebruiksgids uit twee of meer dele kan bestaan:

_ $\quad$ 'n visuele gids (skematiese voorstelling) van die data-inhoud en -struktuur in artikels

- 'n teks wat uit onderskeibare gedeeltes bestaan waarin in elke deel duidelike riglyne (instruksies en/of direktiewe) verskaf word vir die uitvoering van 'n bepaalde funksie met die hulp van die woordeboek

- ' $n$ teks wat op basis van die linguistiese benadering ' $n$ uiteensetting gee van die makrostruktuur en van die linguistiese inhoud en struktuur van die artikels

Soos hierbo uiteengesit, is Nielsen $(2006,2009)$ se voorstel dus dat die linguistiese en die funksionele benaderings mekaar kan komplementeer.

Nielsen (2009: 218) verskaf 'n duidelike aantal funksioneel georïenteerde riglyne vir resensente vir die evaluering van die voortekste, en in die besonder gebruikstekste, van woordeboeke:

- die mate waarin die beoogde funksies (teksresepsie, teksproduksie, ensovoorts) uiteengesit word

- die mate waarin rekenskap gegee word van die omvang van die woordeboek (byvoorbeeld linguisties, vakspesifiek, ensovoorts)

- die mate waarin die teikengebruikers van die woordeboek aangedui en afgebaken word

- die mate waarin die empiriese basis van die woordeboek uiteengesit word

- (meer spesifiek gerig op die evaluering van die gebruiksteks) of die gebruiksgids aandui hoe gebruikers die woordeboek moet gebruik vir elkeen van die beoogde funksies daarvan

- of die gebruikersgids aandui watter data in die woordeboek voorkom

- of die gebruikersgids aandui waar in die woordeboek elke datatipe gevind kan word

- of aangedui word hoe data in die buitetekste verband hou met of komplementerend optree ten opsigte van die data in die sentrale woordelys en ander buitetekste 
- of aangedui word in watter gebruiksituasie die opgenome data waarskynlik (indien nie empiriese navorsing hieroor gedoen is nie - PHS) sal kan help

\section{'n Raamwerk vir die ontleding, beskrywing, beoordeling en motivering van leksikografiese evalueringskriteria}

Die bespreking van die leksikografiese probleem hierbo noodsaak dat daar vir die skryf van ' $n$ resensie 'n duidelike onderskeid getref moet word tussen ten minste ' $\mathrm{n}$ analities of deskriptiewe term (byvoorbeeld raamstruktuur, makrostruktuur, lemma en uitspraak) en 'n evalueringskriterium, dit is, breed gedefinieer, enige standaard, norm, beginsel, praktiese norm of reël of prosedure op basis waarvan die ontwerpelemente van ' $n$ woordeboek (as negatief of positief) beoordeel word.

Wat laasgenoemde betref, is dit verder nodig om te onderskei tussen

- die aspek van die ontwerp van 'n woordeboek waarop 'n evalueringskriterium betrekking het (byvoorbeeld die struktuur van 'n woordeboekartikel of leksikografiese definisies/betekenisverklarings)

- die inhoud en struktuur van 'n evalueringskriterium (byvoorbeeld: definisies/betekenisverklarings moet vir die gebruiker verstaanbaar wees. (stelling); Is die definisies vir die gebruiker verstaanbaar? (vraag)), of dat die gebruiker uit die aangebode data in 'n woordeboek die nodige inligting moet kan ontsluit wat hy of sy vir 'n bepaalde funksie in 'n bepaalde konteks nodig het)

- hoe evalueringskriteria geoperasionaliseer of toegepas kan word in die evaluering van 'n ontwerpkenmerk van 'n woordeboek (byvoorbeeld, hoe kan bepaal word of definisies deur die gebruikers verstaan word, of dat hulle inderdaad uit die aangebode data in 'n woordeboek die nodige inligting vir 'n bepaalde funksie suksesvol ontsluit het/kon ontsluit)

- watter motivering daar vir 'n bepaalde evalueringskriterium aangebied (kan) word (byvoorbeeld motivering vanuit 'n aspek van die leksikografieteorie, teoreties-gestuurde empiriese navorsing oor woordeboekgebruik, standaarde vir die ontwerp van bepaalde woordeboeke, gevestigde leksikografiese gebruike, ensovoorts.)

Die volgende aanvullende (maar deels oorvleuelende) raamwerk word verskaf vir die ontleding en beoordeling van die evalueringskriteria wat resensente van woordeboeke en leksikograwe kan inspan - hier met aanpassings en toeligtende voorbeelde) (sien Swanepoel 2013: 593). Die stippellyne dui aan dat die evalueringskategorieë en evalueringskenmerke self nog oop is en om invulling met verdere navorsing vra. 


\section{Inligting wat deur die evalueringskriterium gedek word:}

\section{(a) Strekking:}

Algemeen (geldig vir beoordeling van alle soorte woordeboeke)

Genre-spesifiek (byvoorbeeld, geldig vir eentalige aanleerderswoordeboeke)

Tekssoort-spesifiek (byvoorbeeld, het betrekking op verskillende soorte voortekste, die sentrale woordelys of die agtertekste)

Ontwerpkenmerk-spesifiek (byvoorbeeld, gemik op insluiting, inhoud en struktuur van morfologiese inligting)

\section{(b) Omvattendheid:}

Uitgebreide - Gebrekkige detail; arbitrêr (byvoorbeeld, dek die evaluering van alle morfologiese inligting in 'n artikel of slegs (en vaagweg) gemik op die evaluering van inligting oor afleidings)

\section{Geldigheid/gemotiveerdheid van die evaluaringskriterium:}

\section{Basis van motivering:}

Standaarde

Teorie

Gebruikersnavorsing (insluitende oor taalvaardigheid, leksikografiese naslaanvaardighede, gebruikskontekste en inligtingsbehoeftes van gebruikers)

Leksikografiese praktyk/tradisie

Funksies van die woordeboek

Ontwerpkenmerke van spesifieke woordeboektipes

Vindbaarheid en verstaanbaarheid van inligting (van 'n bepaalde tipe) (byvoorbeeld leksikale definisies)

Nuutheid/uitsonderlikheid van die kriterium:

Hoog - Laag

\section{Aanbiedingsformaat/-struktuur van die evalueringskriterium:}

Instruksie

Vraag

Stelling

Vereistes 
Verduideliking

\section{Toepassing van die evalueringskriterium:}

(a) Vlak van kundigheid wat vir die toepassing van die evalueringskriterium vereis word:

Meganisties toepasbaar (byvoorbeeld, meting van aantal lemmas in 'n woordeboek)

Vakkundigheid vereis vir toepassing (kan slegs toegepas word deur 'n leksikograaf, taalkundige, resensent, ensovoorts; byvoorbeeld, bepaling of definisies verstaanbaar is)

\section{(b) Uitkomste:}

Oop - geslote (enige uitkomste of beperkte of vasgestelde uitkomste van die toepassing van 'n evalueringskriterium)

\section{(c) Operasionalisering:}

(In detail) gespesifiseer — ongespesifiseer

Alhoewel nie volledig nie, is hierdie ontleding 'n voorlopige poging om van die volgende vrae oor die gebruik van leksikografiese evalueringskriteria vir die beoordeling van 'n omvattende woordeboek, soos die dele van die WAT, te beantwoord:

- Watter kriteria word in die beoordeling van die ontwerpkenmerke van 'n omvattende, sinchronies verklarende woordeboek gebruik?

- Wat is die status van die evalueringskriteria, of hoe geldig is hulle vir die beoordeling van 'n omvattende verklarende woordeboek? Bestaan daar 'n goeie motivering vir die evalueringskriteria?

- Kan die evalueringskriteria geoperasionaliseer word of is hulle toepassing afhanklik van die intuïsie van 'n resensent?

- Kan die evalueringskriteria omskep word in praktiese riglyne vir die ontwerp van omvattende verklarende woordeboeke?

- Is daar empiriese bewyse daarvoor dat die toepassing van die evalueringskriteria (geformuleer as ontwerpheuristieke) die funksionaliteit van nuwe woordeboeke of die hersiening van bestaande woordeboeke sal verhoog?

Die bostaande is spesifiek op die beskrywing en beoordeling van evalueringskriteria gemik. Intussen het Feinauer (2007) met die beskrywing en evaluering van WAT Deel XII in haar resensie ook 'n sistematiese raamwerk vir die orde- 
ning van hierdie kriteria en hulle toepassing gestel deur die raamstruktuur van 'n woordeboek hiervoor te benut, naamlik beskrywing en beoordeling van die voortekste, die sentrale woordelys en die agtertekste van 'n woordeboek. (Sien ook Gouws en Prinsloo (2005) se bespreking van die raamstruktuur van woordeboeke.)

\section{Beskrywing en evaluering van die ontwerpkenmerke van WAT Deel XIV}

WAT Deel XIV is gepubliseer in 2013 met dr. W.F. Botha as hoofredakteur. Naas hierdie deel, word nog twee dele beplan vir die voltooiing van die letter $S$.

Die ontwerp van die raamstruktuur van WAT Deel XIV volg dié van WAT Deel XIII: vier voortekste (Inleiding, Skematiese voorstelling van inskrywings, Toeligting by die gebruik van die Woordeboek en Redaksionele afkortinge, pp. I-XXI), die sentrale woordelys (wat die Afrikaanse woordeskat dek van S-Skooi, pp. 1-637) en twee agtertekste (Bronne waaruit in hierdie deel van die Woordeboek aangehaal is, pp. 638-672, en Verbeterings in Deel XII van die Woordeboek, pp. 673-674).

Hieronder word eers ' $n$ aantal aspekte van die buitetekste bespreek alvorens die sentrale woordelys aan bod kom. As beskrywings- en evalueringsraamwerk word hier op die voorafgaande bespreking gesteun sonder dat alle fasette van hierdie raamwerk weer in besonderhede bespreek word.

\section{Voortekste}

Die afdeling Inleiding bevat hoofsaaklik inligting wat nie met die sentrale woordelys geïntegreer is nie. Sake soos die befondsing van die WAT, publikasies wat sedert 2009 verskyn het, digitalisering van die WAT se materiaalversameling, personeelsake, vakkundige medewerkers, 'n versoek om inligting en 'n versoek vir materiaalbydraes en kommentaar kom aan bod.

Wat opvallend in hierdie teks vanuit 'n evalueringsoogpunt is, is wel die (kort) missiestelling van die WAT (p. V) - 'n tipiese illustrasie van hoe vaag missiestellinge kan wees:

Die missie van die WAT is om die Afrikaanse taal en die gebruikers daarvan te dien, asook die leksikografie in die algemeen, veral die Suid-Afrikaanse leksikografie.

Uit hierdie stelling kan twee kriteria vir die evaluering van hierdie deel van die WAT afgelei word, naamlik spesifisering van die teikengroep en die beoogde funksies van hierdie deel van die WAT. Hieruit blyk in die besonder dat die WAT 'n veel breër groep gebruikers (of miskien meer vaag geformuleer: belanghebbendes) in die oog het as wat vermeld word in die eerste paragraaf van die Toeligting by die gebruik van die woordeboek, p. VIII ("alle sprekers van Afrikaans ... maar veral die spektrum gebruikers wat strek vanaf senior hoërskoolleerders tot Afrikaansakademici"). Volgens die missie is die teikengroep 
alle gebruikers van Afrikaans, Afrikaans as taal, die (beoefenaars van die) leksikografie (-teorie en -praktyk?) op internasionale vlak en Suid-Afrikaanse beoefenaars van die leksikografie (-teorie en -praktyk?). Soos dikwels gebruiklik, is die doelstelling/missie gepas vaag gehou vir sover dien 'n multisemantiese leksikale item is waarvan die presiese betekenis (doelstellings/funksie) nie omskryf word nie. Dit is dus moeilik om uit die missiestelling ' $n$ gemotiveerde evalueringskriterium vir die WAT (of 'n deel daarvan) af te lei. Hoe bepaal mens byvoorbeeld of ('n deel van die) WAT die gebruikers van Afrikaans of die internasionale of Suid-Afrikaanse leksikografie dien en wat dien in hierdie konteks sou beteken?

Feinauer (2007: 259) interpreteer die missie van die WAT egter in haar resensie as sou die missiestelling betrekking hê op die evaluering van bepaalde ontwerpkenmerke van WAT, Deel XII. In die opsomming van haar artikel maak sy die uitspraak dat die buitetekste met die sentrale teks geïntegreer is "en in daardie opsig dus wel die leksikografie dien". Verder is die slotsom dat die gebruikers van die Afrikaanse taal sowel as die Suid-Afrikaanse leksikografie "meer daarby sal baat" as die sentrale teks "deegliker gekonseptualiseer en beplan sou word aan die hand van leksikografiese funksies". As verdere tekens van hoe die WAT dan wel sy "dienstaak" suksesvol sou kon uitvoer, word die volgende genoem: opname van leksikale items moet aan die hand van 'n goed beplande korpus herbedink word, frekwent gebruikte woorde moet nie by lemmakeuses oor die hoof gesien word nie, die lengte van artikels moet gelykvormig gebalanseer word en 'n gebalanseerde verteenwoordiging van makroen mikrostruktuur, wat ook daartoe sal lei dat daar minder onbewerkte lemmatekens is.

Daar word hier volstaan met die opmerking dat dit nie duidelik is hoe dien en die relevante evalueringskriteria in mekaar steek nie. Weliswaar kan daar verskillende evalueringskriteria vir die WAT uit Feinauer (2007) se opsomming afgelei word, al word nie een van hulle onafhanklik gemotiveer nie. Miskien is die eerste probleem dat die WAT met so ' $n$ vae missiestelling volstaan en nie presies duidelikheid gee oor wat dien in hierdie konteks beteken nie. Duidelik het resensente en leksikograwe hier leiding nodig oor die funksie, inhoud en struktuur van 'n missiestelling en 'n duidelike beskrywing van die evaluering daarvan.

'n Tweede probleem is die feit dat daar nie in die afdeling Toeligting by die gebruik van die Woordeboek 'n verdere presiese afbakening van die teikengebruikers en die beoogde funksies van die WAT gegee word nie, of presies hoe teikengebruikers en funksies die ontwerpkenmerke van 'n deel van die WAT bepaal nie. Alle gebruikers van Afrikaans, hoërskoolleerders, en Afrikaansakademici is 'n besonder heterogene groep wat groot verskille sou kon toon ten opsigte van hulle eie kennis van Afrikaans, woordeboeknaslaanvaardighede en die funksies waarvoor hulle die WAT in bepaalde gebruikskontekste sou wou raadpleeg. Dit is nie te voorspel watter radikale veranderinge dit aan die ontwerp van die dele van die WAT kon impliseer nie. 'n Mens vermoed egter dat indien die samestellers die taak van die WAT sien as om die ganse woordeskat 
van Afrikaans in al sy verskyningsvorme te dokumenteer (sien Botha 2006), dan is ' $n$ deskriptiewe funksie heelwaarskynlik die primêre een. So 'n uitgangspunt sou ook strook met die struktureel deskriptiewe benadering wat tot die inhoud en struktuur van die artikels in die sentrale woordelys ingeneem word. Dié kan mens aflees uit die skematiese voorstelling van inskrywings (pp. VI-VII), al die datakategorieë wat in die toeligting by die gebruik van die woordeboek (pp. VIIIXXI) bespreek word en die datakategorieë wat in elke artikel aan die bod kom. Dit sou ook strook met 'n bron soos Zgusta (1971) wat uitvoerig ingaan op die taalkundige begronding van die omvattende (sinchroniese) woordeboek. As sodanige is WAT Deel XIV 'n baie deeglike omvattende sinchroniese woordeboek, waarvan net die kenmerke self in die toeligting by die gebruik van die woordeboek sekuur omskryf word (sien p. VIII).

Dit hou egter nie in dat die woordeboek nie wel 'n multifunksionele gebruik beoog nie. Tarp en andere het reeds lankal daarop gewys dat mens nie in die geval van gedrukte woordeboeke kan verwag dat daar vir elke moontlike funksie 'n monofunksioneel ontwerpte woordeboek beplan en uitgegee moet word nie (sien Bergenholtz en Bothma 2011: 60). Gegee die talle funksies waarvoor woordeboeke gebruik sou kon word, sal dit tot 'n (onbekostigbare) proliferasie van woordeboeke kan lei. Aan die ander kant word daarmee nie ontken dat die samestellers wel deeglik in die toeligting tot die gebruik van woordeboeke wel vir gebruikers touwys moet maak oor hoe 'n woordeboek soos die (verskillende dele van die) WAT vir bepaalde, goed omskrewe funksies benut kan word nie. Die breër probleem wat hierdie saak aan die orde stel is: Wat verwag gebruikers en leksikograwe van 'n "goeie" gebruiksgids? Aan watter vereistes moet dit voldoen en hoe evalueer mens dit? Dit is 'n onderwerp wat selde aan die orde gestel word. (Sien in hierdie verband egter Gouws 2007; Nielsen 2006, 2009.)

Aanvaar 'n mens dat die praktiese leksikografie deur ontwikkelinge op die gebied van die leksikografieteorie gevoed moet word (sien Botha 2004), dan sou 'n mens wel kon verwag dat die samestellers van die WAT van die sake wat hierbo genoem word, rekenskap moet gee, sy dit in die WAT self of enige ander gepubliseerde bron.

Vir eie gebruik, het ek die toeligting by die gebruik van die woordeboek te lank en ingewikkeld gevind. Alhoewel volledig, sou mens vir groter gebruiksvriendelikheid kon vra. Indien uit navorsing gemotiveer, sou mens graag wou sien dat die herskrywing van die inleiding, in die besonder inligting oor die gebruik van die woordeboek (of dan dele daarvan), in die toekoms aandag kry.

\section{Agtertekste}

Die teks onder Bronne waaruit in hierdie deel van die Woordeboek aangehaal is (pp. 638672), moet in twee verdeel word: 'n afdeling Toeligting (p. 638), waarin die redaksionele beleid ten opsigte van die opname van bronne en verwysings na bronne op ' $n$ baie insigtelike wyse uiteengesit word, al word daar in hierdie teks geen motivering vir die gekose werkswyse gebied nie. Die tweede deel 
(pp. 639-672) bestaan uit 'n omvangryke lys van die gekose bronne in ooreenstemming met die beleid wat in die inleidende paragrawe onder die hofie Toeligting uiteengesit word. Laasgenoemde is dus geïntegreer met die res van die bronnelys en dié weer met die verwysings (sitate) wat as voorbeeldmateriaal in die artikels van die sentrale woordelys voorkom. In die geheel gesien, dra hierdie teks dus by tot die integrasie van die tekste van hierdie deel van die WAT. Hierdie evalueringskriterium het dus betrekking op die inhoud, struktuur en funksie van die verskaffing van die bronne waaruit daar in die sentrale woordelys vir verwysings (sitate in die besonder) gesteun word. Die motivering van hierdie gebruikswyse van bronne ontbreek, en aangesien alternatiewe verwysingstrukture en bronverwysings moontlik is, is dit opvallend dat daar vir die verkose werkwyse geen motivering gegee word nie.

Die teks Verbeterings in Deel XIII van die Woordeboek, in WAT Deel XIV, pp. 673-674, is 'n baie kort teks van twee bladsye met regstellings en verbeterings op die sentrale deel van WAT Deel XIII. Feinauer (2007: 264) het alreeds met ' $n$ resensie van WAT Deel XII daarop gewys dat so ' $n$ teks met verbetering en regstellings in WAT Deel XI nie met die ander tekste van WAT Deel XII te make het nie. Dieselfde geld die insluiting van ' $n$ lys met regstellings aan WAT Deel XIII in Deel XIV. Die probleem met hierdie werkwyse is natuurlik dat die gebruikers nooit in 'n vorige deel alreeds en duidelik vertroud gemaak word met hierdie aanbieding van regstellings nie sodat hulle sal weet dat wat daar ook al fout met ' $n$ deel is (weglatings, drukfoute, inkonsekwenthede in redaksionele beleid, opname van onverklaarde lemmas, ensovoorts) in 'n daaropvolgende deel gepubliseer sal word. Uiteraard kan die regstellings deels gemotiveer word op basis van resensies, leksikografiese literatuur of suiwer op basis van die proefleeswerk van die redakteurs van die WAT. Miskien sal gebruikers baat vind by ' $n$ inleiding wat help om die artikels van hierdie veranderinge te verduidelik. Of gebruikers so 'n inleiding inderdaad nodig ag en nut daarvan sal hê, is 'n empiriese vraag wat empiriese navorsing vereis.

Dieselfde geld ten opsigte van twee ander oorwegings wat al twee die implikasie het dat die omvang van elke nuwe deel van die WAT sal vergroot, en, bykomend, of dit as geregverdig/gemotiveerd beskou kan word as mens dit opweeg teen die addisionele koste, personeelbeperkinge maar veral die poging om die WAT te voltooi.

Feinauer (2007: 264) lewer byvoorbeeld kommentaar op die feit dat die agtertekste nie benut word vir geïntegreerde tekste van inligtingskomponente wat verspreid in 'n woordeboekdeel (in aparte artikels of as deel van verskillende artikels) voorkom nie (byvoorbeeld 'n geïntegreerde lys met afkortings of met etimologiese inligting). Die vraag is natuurlik waar die woordeboekmakers op gemotiveerde wyse die grens sou moes trek met die opname in aparte tekste van hierdie soort inligting - daar kom immers talle datatipes in elke artikel voor. Samestellers van hierdie soort woordeboek het natuurlik ook die taak om te keer dat die omvang van enige deel van die WAT buite koste, hanteerbaarheid van inligting, ensovoorts eskaleer. Trouens, met die hersienings van die redaksionele beleid van die WAT is daar juis besluit om af te skaal wat die 
inhoud van die WAT betref, soos byvoorbeeld die opname van vakterme en illustrasies.

Feinauer (2007: 264) wys verder daarop — en dit sou ook geld ten opsigte van WAT XIV - dat agtertekste nie benut word om nog bykomende data by dié in die sentrale woordelys te voeg nie (byvoorbeeld die opname as agterteks van geografiese name en hulle afleidings, natuurlik wat binne die beperking $S-$ Skooi val).

'n Bykomende oorweging is dié van Gouws (2007) (sien ook Feinauer 2007: 264-265), naamlik om die agtertekste te gebruik vir gebruiksfunksies waarvoor die sentrale woordelys nie (primêr) voorsiening maak nie. As voorbeeld gee hy die gebruik van illustrasies en name van vleissnitte of ' $n$ wêreldkaart met ' $n$ verskeidenheid geografiese inligting om die kognitiewe funksie van 'n woordeboek te ondersteun (Gouws 2007: 84-85). In die beoordeling van die invoeging of weglating van agtertekste geld ook beperkings van uitgawes, personeeltekorte en voltooiingsdatums, maar veral ook 'n grondige besinning en empiriese navorsing oor die beoogde funksies van die WAT (sien die bespreking hierbo).

\section{Die sentrale woordelys}

Die sentrale woordelys vorm die hoofteks van elke deel van die WAT. Dit is egter dikwels ook die moeilikste aspek van 'n woordeboek om te beoordeel omdat ' $n$ resensent meestal nie so 'n omvattende woordeboek van die eerste tot die laaste bladsy sistematies deurwerk en elke teks, artikel, databewerking, ensovoorts evalueer aan die hand van relevante kriteria nie. Soos Svensén (2009: 482-485) ook aanbeveel, moet die resensent volstaan met steekproewe wat beoordeel word teen die redaksionele beleid van die samestellers van die woordeboek self. Alhoewel Svensén (2009: 482) die beleid van die samestellers van 'n woordeboek as primêre evalueringskriterium voorhou, meld hy ook dat baie woordeboeke nie hierdie inligting verskaf nie. En soos hierbo aangevoer, word in spesifieke woordeboeke dikwels net vaagweg aan hierdie sake aandag gee. In sulke gevalle is die resensent dus, soos Svensén (2009: 482) aanvoer, afhanklik van algemeen aanvaarde evalueringskriteria wat onafhanklik bestaan van die woordeboek wat geresenseer word.

In resensies van die dele van die WAT, sien byvoorbeeld Feinauer (2007) en McLachlan (2013), word meestal al twee hierdie werkwyses gevolg. Aspekte van die sentrale woordelys wat meestal aan bod kom, is 'n kritiese evaluering van die redaksionele beleid van die WAT en die ooreenstemming met die beleid en die makro- en mikrostrukturele kenmerke van die sentrale woordlys (byvoorbeeld redaksionele inkonsekwenthede in die toepassing van hul eie beleid, soos weglating van lemmas of lemmatipes, die opname van moeilik interpreteerbare lemmas as onverklaarde lemmas, foute of gebreke in die bewerking van spesifieke lemmas, meer spesifiek, probleme met die bewerking van spesifieke datakategorieë, soos spelling, uitspraak, woordsoort, etimologie, 
morfologie, leksikale definisies, verwysingsmetodes, gebrekkige gebruik van ortografiese struktuurmerkers met die onderskeiding van datatipes, ensovoorts.) Hierdie soort probleme is reeds goed bekend vir resensente en samestellers van die dele van die WAT en dit hoef nie verder ten opsigte van WAT Deel XIV uitgewys te word nie. Dié is sake waaraan die samestellers aandag moet gee (met hersienings en die beplanning en uitvoering van nuwe dele) en resensente hulle eie evaluerings op goedgemotiveerde kriteria moet baseer. Innoverend is wel die wyse waarop resensente voorstelle vir veranderinge en verbeteringe aan 'n deel van die WAT voorstel op basis van ontwikkelinge op die gebied van die leksikografieteorie en -praktyk. Sulke bydraes dien om leksikograwe hulle eie praktyk voortdurend krities te laat bekyk en, waar nodig, met innoverende oplossings vorendag te kom.

Uiteraard is resensies nie net gemik op kritiek nie. Vir sover woordeboeke konsekwent aan hulle redaksionele beleid hou, onder meer, word positiewe beoordeling van verskeie aspekte van die dele van woordeboeke gegee (sien byvoorbeeld weer Feinauer 2007 en McLachlan 2010). Wat die WAT en ook WAT Deel XIV betref, geld die omvattende opname van lemmas en hulle bewerking. Daar is geen gebrek aan voorbeelde hiervan as mens in hierdie deel van die WAT begin lees nie. Mens staan telkens opnuut verbyster oor die omvang van die Afrikaanse woordeskat wat daarin opgeneem is en die omvang van hulle bewerking.

\section{Ten slotte}

Een van die evalueringskriteria van goeie resensies is dat die slotevaluering van ' $n$ woordeboek moet korreleer met voorafgaande evaluerings van die ontwerpaspekte daarvan (sien die bespreking hierbo). Die voorafgaande paragraaf oor die positiewe kenmerke van die WAT sou as 'n oortreding van hierdie beginsel gesien kan word. Hierdie artikel is egter nie uit en uit 'n resensie van WAT Deel XIV nie, maar eerder 'n artikel in die kategorie resensie-artikel vir sover dit 'n poging is om resensies oor die algemeen op 'n stewiger teoretiese voet te plaas, veral ten opsigte van evalueringskriteria. Soos die praktyk laat blyk, steur samestellers van woordeboeke hulle dikwels nie aan die evaluerings van resensente nie, nog minder aan die jongste ontwikkelinge op die gebied van die leksikografieteorie en -praktyk. Dikwels gaan dit om ander, ewe geldige redes, maar as aanvaar word dat die leksikografiepraktyk positief deur die leksikografieteorie gelei moet word, dan is dit van belang dat mens weer krities oor die evalueringskriteria van leksikograwe en resensente moet besin.

\section{Bronnelys}

\section{Woordeboeke}

Van Schalkwyk, D.J. (Hoofred.). 2000. Woordeboek van die Afrikaanse Taal. Elfde Deel. Stellenbosch: Buro van die WAT. 
Botha, W.F. (Hoofred.). 2005. Woordeboek van die Afrikaanse Taal. Twaalfde Deel. Stellenbosch: Buro van die WAT.

Botha, W.F. (Hoofred.). 2009. Woordeboek van die Afrikaanse Taal. Dertiende Deel. Stellenbosch: Buro van die WAT.

Botha, W.F. (Hoofred.). 2013. Woordeboek van die Afrikaanse Taal. Veertiende Deel. Stellenbosch: Buro van die WAT.

\section{Ander}

Atkins, B.T.S. en M. Rundell. 2008. The Oxford Guide to Practical Lexicography. Oxford/New York: Oxford University Press.

Bergenholtz, H. en T.J.D. Bothma. 2011. Needs-adapted Data Presentation in e-Information Tools. Lexikos 21: 53-77.

Boshoff, S.P.E. 1926. 'n Standaardwoordeboek van Afrikaans. Gedenkboek ter eere van die Genootskap van Regte Afrikaners (1875-1925): 307-328. Potchefstroom: Afrikaanse Studentebond.

Botha, W. 2004. Die impak van kritiek op die samestelling van die Woordeboek van die Afrikaanse Taal. Lexikos 14: 1-16.

Botha, W. 2006. Kom ons doen dit vir Afrikaans. Die WAT word 80. Eikestadnuus, 24 Maart 2006.

Chan, A.Y.W. en A. Taylor. 2001. Evaluating Learner Dictionaries: What the Reviews Say. International Journal of Lexicography 14(3): 163-180.

Combrink, J.G.H. 1962. 'n Prinsipiële beskouing oor WAT IV. Tydskrif vir Geesteswetenskappe 2(4): 199-221.

Combrink, J.G.H. 1979. Die sesde deel van die W.A.T. Standpunte 140, 32(2): 49-64.

Cumming, G., S. Crop en R. Sussex. 1994. On-line Lexical Resources for Language Learners: Assessment of Some Approaches to Word Definition. System 23(3): 369-377.

Feinauer, I. 1996. Die negende deel van die Woordeboek van die Afrikaanse Taal. Lexikos 6: 233-271.

Feinauer, I. 2007. Doen die Woordeboek van die Afrikaanse Taal Deel XII dit vir die Afrikaanse taal en die Suid-Afrikaanse leksikografie? Lexikos 17: 259-277.

Fontenelle, T. (Red.). 2008. Practical Lexicography: A Reader. Oxford: Oxford University Press.

Gouws, R.H. 1985. Die sewende deel van die Woordeboek van die Afrikaanse Taal. Standpunte 178, 38(4): 13-25.

Gouws, R.H. 1994. Woordeboek van die Afrikaanse Taal, Deel IX. Bespreking gelewer op die SAUKradioprogram Skrywers en Boeke.

Gouws, R.H. 2007. A Transtextual Approach to Lexicographic Functions. Lexikos 17: 77-87.

Gouws, R.H. 2011. The Woordeboek van die Afrikaanse Taal. Grundlingh, A. en S. Huygen (Reds.). 2011. Reshaping Remembrance. Critical Essays on Afrikaans Places of Memory: 137-143. Amsterdam: Rozenberg Publishers.

Gouws, R.H. 2014. Leksikografie. Carstens, W.A.M. en N. Bosman (Reds.). 2014: Kontemporêre Afrikaanse Taalkunde: 373-407. Pretoria: Van Schaik.

Gouws, R.H. en D.J. Prinsloo. 2005. Principles and Practice of South African Lexicography. Stellenbosch: SUN MeDIA.

Grobler, H. 1978. 'n Voorlopige toepassing van S.P.E. Boshoff se kriteria vir 'n groot woordeboek op WAT I-VI. Klasgids 12(4): 29-46.

Hausmann, F.J., O. Reichmann, H.E. Wiegand en L. Zgusta (Reds.). 1989-1991. Wörterbücher. Ein 
internationales Handbuch zur Lexikographie/Dictionaries. An International Encyclopedia of Lexicography/Dictionnaires. Encyclopédie internationale de lexicographie. Berlin/New York: Walter de Gruyter.

McLachlan, J.D. 2010. Resensie. Woordeboek van die Afrikaanse Taal, Dertiende Deel: R. Lexikos 20: 750756 .

Nielsen, S. 2003. Anmeldelse af ordbøger. LexicoNordica 10: 27-44.

Nielsen, S. 2006. A Functional Approach to User Guides. Dictionaries. Journal of the Dictionary Society of North America 27: 1-20.

Nielsen, S. 2009. The Evaluation of the Outside Matter in Dictionary Reviews. Lexikos 19: 207-224.

Odendal, F.F. 1961a. Leksikografiese probleme I. Standpunte 14(6): 53-61.

Odendal, F.F. 1961b. Leksikografiese probleme II. Standpunte 15(1): 49-54.

Odendal, F.F. 1962. Leksikografiese probleme III. Standpunte 16(5): 48-55.

Ripfel, M. 1989. Wörterbuchkritik. Eine empirische Analyse von Wörterbuchrezensionen. Lexicographica Series Maior 29. Tübingen: Max Niemeyer.

Svensén, B. 2009. A Handbook of Lexicography. The Theory and Practice of Dictionary-making. Cambridge: Cambridge University Press.

Swanepoel, P. 2000. Providing Lexicographic Support for SL Vocabulary Acquisition: What Kind, under What Conditions, for Whom, and Why? Heid, U., S. Evert, E. Lehmann and C. Rohrer (Reds.). 2000. Proceedings of the Ninth EURALEX International Congress, EURALEX 2000, Stuttgart, Germany, August 8th-12th, 2000: 403-418. Stuttgart: Universität Stuttgart, Institut für Maschinelle Sprachverarbeitung.

Swanepoel, P. 2008. Towards a Framework for the Description and Evaluation of Dictionary Evaluation Criteria. Lexikos 18: 207-231.

Swanepoel, P. 2013. Evaluation of Dictionaries. Gouws, R.H., U. Heid, W. Schweickard en H.E. Wiegand (Reds.). 2013. Dictionaries. An International Encyclopedia of Lexicography. Supplementary Volume: Recent Developments with Focus on Electronic and Computational Lexicography: 587-596. Berlyn/New York: De Gruyter Mouton.

Tarp, S. 2004a. Basic Problems of Learner's Lexicography. Lexikos 14: 222-252.

Tarp, S. 2004b. Reflections on Dictionaries Designed to Assist Users with Text Production in a Foreign Language. Lexikos 14: 299-325.

Tarp, S. 2009. Reflections on Lexicographical User Research. Lexikos 19: 275-296.

Van Sterkenburg, P. (Red.). 2003. A Practical Guide to Lexicography. Amsterdam/Philadelphia: John Benjamins.

Wiegand, H.E. 1996. A Theory of Lexicographic Texts: An Overview. Suid-Afrikaanse Tydskrif vir Taalkunde 14(4): 134-149.

Zgusta, L. 1971. Manual of Lexicography. The Hague: Mouton. 